\title{
Differential metabolism of deoxyribonucleosides by leukaemic T cells of immature and mature phenotype
}

Yechezkel Sidi, N. Lawrence Edwards, Charles Winkler, * Paul Bunn* And BeVerly S. Mitchell Simpson Memorial Research Institute, Department of Internal Medicine, University of Michigan, Ann Arbor, Michigan, and *NCI-Navy Medical Oncology Branch, National Cancer Institute and Naval Hospital, Bethesda, Maryland

Received 20 June 1984; accepted for publication 9 January 1985

Summary. Experimental evidence has indicated that $\mathrm{T}$ lymphoblasts are more sensitive to deoxynucleoside toxicity than are $B$ lymphoblasts. These data have led to the use of purine enzyme inhibitors as selective chemotherapeutic drugs in the treatment of $T$ cell malignancies ranging from $T$ cell acute lymphoblastic leukaemia to cutaneous $\mathrm{T}$ cell lymphomas. We have compared the toxicities of 2 -deoxyadenosine, 2'-deoxyguanosine, and thymidine for $\mathrm{T}$ cell lines derived from patients with $\mathrm{T}$ cell acute lymphoblastic leukaemia with those for mature $\mathrm{T}$ cell lines derived from patients with cutaneous T cell leukaemia/lymphoma. We have found that both deoxynucleosides are far less toxic to the mature $\mathrm{T}$ cell lies than to $\mathrm{T}$ lymphoblasts and that the mature cells accumulate much lower amounts of dATP and dGTP when exposed to deoxyadenosine and deoxyguanosine, respectively. Similar studies performed on peripheral blood cells from patients with $\mathrm{T}$ cell leukaemias of mature phenotype and on peripheral blood $\mathrm{T}$ cells demonstrate similar low amounts of deoxynucleotide accumulation. Measurements of the activities of several purine metabolizing enzymes that participate in deoxynucleoside phosphorylation or degradation do not reveal differences which would explain the toxicity of deoxynucleosides for immature, as compared to mature, T cells. We conclude that deoxynucleoside metabolism in leukaemic $\mathrm{T}$ cells varies with their degree of differentiation. These observations may be relevant to the design of chemotherapeutic regimes for $\mathrm{T}$ cell malignancies.

Two inborn errors of purine metabolism have been associated with severe numerical deficits of mature T lymphocytes. Adenosine deaminase (ADA) deficiency results in severe combined Correspondence: Dr Beverly S. Mitchell, Simpson Memorial Research Institute, 102 Observatory, Ann Arbor, MI 48109. U.S.A. 
immunodeficiency disease, generally with a more profound loss of T than of B cells (Giblett $e t$ al, 1972), whereas purine nucleoside phosphorylase (PNP) deficiency results in an isolated T cell deficit (Giblett et al, 1975). The loss of $T$ lymphocytes in these disorders was initially attributed exclusively to the selective metabolism of the deoxynucleoside substrates of these enzymes ( 2 -deoxyadenosine ( $\mathrm{AdR})$ in the case of ADA deficiency and $2^{\prime}$-deoxyguanosine (GdR) in the case of PNP deficiency) to the corresponding deoxynucleoside triphosphate (dATP or dGTP) in T cells (Coleman et al, 1978; Mitchell et al, 1978; Carson et al, 1978). The $\mathrm{T}$ cells employed in the in vitro studies leading to this hypothesis were cultured lymphoblasts initially derived from patients with $\mathrm{T}$ cell acute lymphoblastic leukaemia.

Clinical studies with the ADA inhibitor, 2 '-deoxycoformycin, have indeed confirmed that dATP readily accumulates in the lymphoblasts from patients with $\mathrm{T}$ cell acute lymphoblastic leukaemia when ADA is inhibited in vivo and that $\mathrm{AATP}$ accumulation is associated with cytotoxicity (Prentice et al, 1981; Mitchell et al, 1980; Grever et al, 1981). In addition, however, 2'-deoxycoformycin induces profound lymphopenia in patients with solid tumours (Smyth, 1979), as well as in patients with cutaneous T cell lymphomas (Siaw et al, 1980; Grever et al, 1983) and chronic lymphocytic leukaemia of T cell origin (Hallam et al, 1984). In contrast to the studies on T lymphoblasts, the mechanism(s) underlying the lysis of mature normal and malignant $\mathrm{T}$ cells has (have) not yet been definitively established. We have therefore compared the cytotoxic effects and metabolism of AdR, GdR and thymidine (TdR) in leukaemic lymphoid cells and cell lines of mature phenotype with those in immature $T$ lymphoblasts.

\section{MATERIALS AND METHODS}

Reagents. 2'-Deoxycoformycin was a gift of the Warner-Lambert Co., Ann Arbor, Mich. The PNP inhibitor, 8-aminoguanosine, was obtained from Dr Leroy Townsend, Department of Medicinal Chemistry, University of Michigan, Ann Arbor, Mich. (Kazmers et al, 1981).

Cell lines and growth experiments. Human T and B lymphoblast lines were obtained, as described previously (Mitchell et al, 1978). The mature T cell lines HUT 78 and HUT 102 have also been described previously (Poiesz et al, 1980; Gazdar et al, 1980). HUT 102 cells were obtained from the lymph node of a patient with adult T cell leukaemia lymphoma and the human T cell leukaemia virus (HTLV) was originally isolated from this cell line. HUT 78 was established from the peripheral blood cells of a patient with the Sezary syndrome and is not infected with HTLV. Both lines have surface antigens reactive with OKT1 and T4 monoclonal antibodies and lack OKT8 antigens.

Exponentially growing cells were suspended at a concentration of $2 \times 10^{5}$ cells $/ \mathrm{ml}$ in RPMI- 1640 medium, 10\% horse serum, and the additives indicated in a final volume of 100 $\mu \mathrm{l}$ in flat-bottom microtitre plates (Corning. N.Y.). Each experiment was performed in triplicate and control growth was exponential over $96 \mathrm{~h}$.

Leukaemic cell isolation and incubations. Mononuclear cells were obtained from the heparinized peripheral blood of normal controls or patients with $\mathrm{T}$ cell leukaemia and separated on Ficoll-Hypaque gradients. Of the four patients studied, one (O.B.) had a T cell leukaemia/lymphoma characterized by severe hypercalcaemia and rapidly progressive 
cutaneous lesions (Bunn et al. 1983). In the leukaemic phase her peripheral blood $T$ cells reacted with the monoclonal anti-Tac antibody and were thus positive for the T-cell growth factor receptor (Leonard et al, 1983). In addition, her serum was positive for antibodies to the major core protein (p24) of HTLV I. She was thus diagnosed as having retrovirus-associated adult $\mathrm{T}$-cell leukaemia/lyphoma. Cells from the other three patients were unreactive with the anti-Tac antibody and all sera were negative for antibodies to HTLV. E.M. was felt to have T cell chronic lymphocytic leukaemia, L.M. a cutaneous T cell lymphoma in the leukaemic phase, and L.K. an unusual and highly malignant $\mathrm{T}$ cell leukaemia of mature phenotype (Schnitzer et al, 1982). Normal peripheral blood T cells were isolated by conventional sheep erythrocyte rosetting techniques.

Cells were incubated at a final concentration of $2 \times 10^{5}$ cells $/ \mathrm{ml}$ in RPMI- 1640 medium with $10 \%$ horse serum and the additives indicated. 2 '-Deoxycoformycin and 8 -aminoguanosine were added 30 min prior to the addition of AdR or GdR to allow maximal inhibition of ADA or PNP activity. Following the incubations, cells were sedimented at $400 \mathrm{~g}$ and extracted in $1 \mathrm{ml} 60 \%$ methanol at $-20^{\circ} \mathrm{C}$ for $24 \mathrm{~h}$. Ribo- and deoxyribonucleotides were separated by high pressure liquid chromatography on a Partisil-10 SAX anion-exchange column (Whatman, Clifton, N.J.), using an ammonium phosphate elution gradient $(0 \cdot 3-0.45 \mathrm{M}, \mathrm{pH} 3 \cdot 3-3 \cdot 6)$ over $35 \mathrm{~min}$ at a flow rate of $2 \mathrm{ml} / \mathrm{min}$. When insufficient cells were available for HPLC analysis, levels of deoxyribonucleoside triphosphates were measured using a modification of the DNA polymerase assay, as previously described (Mitchell et al, 1978).

Measurements of enzyme activities. Cellular cytoplasmic extracts were prepared from approximately $2 \times 10^{8}$ lymphoid cells during exponential growth. The cells were washed twice in Hanks balanced salt solution and resuspended in $1.5 \mathrm{ml} 10 \mathrm{~mm}$ Hepes buffer $\mathrm{pH} 7 \cdot 4$, $0.5 \mathrm{mM} \mathrm{MgCl}_{2}$, and $0.15 \mathrm{M} \mathrm{NaCl}$. An equal volume of $0.5 \mathrm{M}$ sucrose was slowly added to the cold cell suspension and the cells were lysed by nitrogen cavitation bomb at $4^{\circ} \mathrm{C}$, as previously described (Mitchell \& Edwards, 1984). Assays for ecto-5-nucleotidase activity, ADA and PNP activities were performed as previously described (Wortman $e t$ al, 1979), as were the assays for adenosine kinase, deoxycytidine kinase, and deoxyadenosine phosphorylating activity (Hurley \& Fox, 1983). Final substrate concentrations were $17 \mu \mathrm{M}$ for adenosine, $20 \mu \mathrm{M}$ for GdR, and $500 \mu \mathrm{M}$ for AdR.

\section{RESULTS}

\section{Effects of the deoxynucleosides on cell growth and metabolism}

The effects of deoxynucleosides, AdR, GdR and TdR, on the growth of cultured cutaneous T cell leukaemia cell (CTCL) lines are compared to their effects on the growth of human $\mathrm{T}$ and $\mathrm{B}$ lymphoblasts in Table I. Previous studies have demonstrated marked enhancement of AdR toxicity for T lymphoblasts by the ADA inhibitor 2'-deoxycoformycin (Sylwesterowicz et al, 1982) and of GdR toxicity by the PNP inhibitor, 8-aminoguanosine (Kazmers et al, 1981). Neither inhibitor alone has any effect on cell growth. Hence, comparison of AdR and GdR toxicities are made in the presence of $2^{\prime}$-deoxycoformycin or 8-aminoguanosine, respectively. It is apparent that the $\mathrm{ID}_{50} \mathrm{~S}$ of $\mathrm{AdR}$ and GdR for the CTCL lines are comparable to those 
Table I. Comparative effects of $2^{\prime}$-deoxyadenosine, $2^{\prime}$-deoxyguanosine and thymidine on the growth of cutaneous $\mathrm{T}$ cell leukemia cell lines. $\mathrm{T}$ lymphoblasts, and $\mathrm{B}$ lymphoblasts

\begin{tabular}{|c|c|c|c|c|c|c|}
\hline & \multicolumn{2}{|c|}{ CTCL } & \multicolumn{2}{|c|}{ T lymphoblasts } & \multicolumn{2}{|c|}{ B lymphoblasts } \\
\hline & HUT 102 & HUT 78 & MOLT 4 & RPMI 8402 & MGL 8 & GM 558 \\
\hline Doubling time (h) & 54 & 54 & 19 & 31 & 36 & 30 \\
\hline \multicolumn{7}{|l|}{$\mathrm{ID}_{50}{ }^{*}$} \\
\hline $\operatorname{AdR}(\mu \mathrm{M})+10 \mu \mathrm{M} d C F$ & 39 & 33 & 0.9 & 0.8 & 58 & 64 \\
\hline GdR $(\mu \mathrm{M})+100 \mu \mathrm{M} 8$-AGuo & 22 & 20 & $1 \cdot 3$ & $0 \cdot 9$ & 18 & 17 \\
\hline $\mathrm{TdR}(\mu \mathrm{M})$ & 350 & 520 & 75 & 18 & 980 & 480 \\
\hline
\end{tabular}

${ }^{*}$ The $\mathrm{ID}_{50}$ is the concentration of deoxyribonucleoside causing $50 \%$ inhibition of growth after $72 \mathrm{~h}$ as compared to control cells grown in the presence of $10 \mu \mathrm{M} 2^{\prime}$-deoxycoformycin, $100 \mu \mathrm{M}$ 8-aminoguanosine, or no additives for AdR, GdR and TdR, respectively. Values represent a mean of three experiments performed in triplicate.

for B lymphoblasts and 20- to 30-fold higher than those for T lymphoblasts. In addition, TdR is far less inhibitory to the growth of CTCL cells and B lymphoblasts than it is to the growth of $\mathrm{T}$ lymphoblasts.

In order to see whether the relative resistance of the mature CTCL lines to deoxynucleosides was reflected in their synthesis and/or accumulation of the corresponding deoxynucleoside triphosphates, CTCL cells, T lymphoblasts and B lymphoblasts were incubated for 4 and $24 \mathrm{~h}$ with (a) $50 \mu \mathrm{M} 2^{\prime}$-deoxyadenosine $+10 \mu \mathrm{M} 2^{\prime}$-deoxycoformycin, and (b) $50 \mu \mathrm{M}$ 2 -deoxyguanosine $+100 \mu \mathrm{M} 8$-aminoguanosine. Cells were extracted and nucleotide pool sizes were determined by HPLC. As summarized in Table II, CTCL cells accumulated far less dATP and dGTP from the corresponding deoxynucleosides at both time points than did the T lymphoblasts, but did not differ significantly from the B lymphoblasts.

Since the CTCL cell lines clearly have been selected for their ability to proliferate indefinitely in tissue culture and since active cell cycling may affect the size of deoxynucleotide pools, leukaemic cells were isolated from the peripheral blood of four patients with $\mathrm{T}$ cell leukaemias of mature phenotype $\left(\mathrm{T}^{+}{ }^{+}\right.$and/or $\left.\mathrm{T} 8^{+}\right)$. The $\mathrm{T} 8^{+}$cells from L.M. accumulated several-fold the baseline level of dATP and dGTP, but cells from the three other patients and normal T lymphocytes failed to accumulate dATP and dGTP under the same conditions.

Since ATP depletion has been invoked as a possible mechanism of mature lymphocyte depletion resulting from deoxycoformycin treatment (Siaw et al, 1980; Carson et al, 1982). A'TP levels were monitored by HPLC in cultured cells incubated with AdR and 2'-deoxycoformycin and the results are shown in Table III. CTCL cells showed a modest rise in ATP levels at $4 \mathrm{~h}$ and a slight decline of ATP levels at $24 \mathrm{~h}$ when compared to cells cultured in the presence of 2'-deoxycoformycin alone. The RPMI-8402 $\mathrm{T}$ lymphoblast line demonstrated a consistent decline in ATP values during the incubations which was not seen in the Molt- $4 \mathrm{~T}$ lymphoblasts. In contrast to both these observations. B lymphoblasts had a pronounced early decline in ATP levels at $4 \mathrm{~h}$ with a recovery to levels higher than the control values at $24 \mathrm{~h}$. 
Table II. DeoxyATP and deoxyGTP accumulation by lymphoid cells in vitro

\begin{tabular}{|c|c|c|c|c|c|c|c|}
\hline \multirow[b]{2}{*}{ Cell type } & \multirow{2}{*}{$\begin{array}{l}\text { Surface } \\
\text { markers }\end{array}$} & \multicolumn{3}{|c|}{$\begin{array}{c}\mathrm{dATP}^{*} \\
\text { (pmol/10 } 10^{6} \text { cells) }\end{array}$} & \multicolumn{3}{|c|}{$\begin{array}{c}\text { dGTP } † \\
\left(\mathrm{pmol} / 10^{6} \text { cells }\right)\end{array}$} \\
\hline & & Control & $4 h$ & $24 \mathrm{~h}$ & Control & $4 \mathrm{~h}$ & $24 \mathrm{~h}$ \\
\hline \multicolumn{8}{|l|}{ CTCL } \\
\hline HUT 78 & $\mathrm{~T}_{4}^{+}$ & $21 \pm 2$ & $69 \pm 1$ & $52 \pm 2$ & $13 \pm 6$ & $26 \pm 11$ & $31 \pm 4$ \\
\hline HUT 102 & $\mathrm{~T}^{+}$ & $14 \pm 6$ & $34 \pm 3$ & $44 \pm 3$ & $19 \pm 5$ & $48 \pm 24$ & $39 \pm 10$ \\
\hline \multicolumn{8}{|l|}{ T lymphoblasts } \\
\hline MOLT 4 & $\mathrm{~T} 11^{+}$ & $18 \pm 5$ & $573 \pm 44$ & $502 \pm 115$ & $15 \pm 4$ & $898 \pm 47$ & $2860 \pm 1129$ \\
\hline RPMI 8402 & $\mathrm{~T} 11^{+}$ & $16 \pm 4$ & $493 \pm 16$ & $2909 \pm 553$ & $13 \pm 4$ & $420 \pm 50$ & $979 \pm 182$ \\
\hline \multicolumn{8}{|l|}{ B lymphoblasts } \\
\hline MGL 8 & $\operatorname{IgM} \kappa$ & $18 \pm 6$ & $27 \pm 7$ & $29 \pm 3$ & $12 \pm 3$ & $16 \pm 4$ & $18 \pm 2$ \\
\hline GM 558 & $\operatorname{IgM} \kappa$ & $24 \pm 4$ & $21 \pm 4$ & $26 \pm 3$ & $16 \pm 5$ & $61 \pm 44$ & $33 \pm 1$ \\
\hline \multicolumn{8}{|l|}{ CTCL patients } \\
\hline E.M. & $\mathrm{T} 11^{+}, \mathrm{T}^{+}{ }^{+}$ & $3 \pm 1$ & $8 \pm 1$ & $5 \pm 1$ & $2 \pm 2$ & $8 \pm 1$ & $8 \pm 1$ \\
\hline O.B. & $\mathrm{T} 1 \mathrm{l}^{+}, \mathrm{T}_{4}^{+}$ & 5 & 13 & & 4 & 6 & \\
\hline L.K. & $\mathrm{T} 11^{+}, \mathrm{T}_{4}^{+}, \mathrm{T} 8^{+}$ & 5 & 4 & 2 & 4 & 4 & 3 \\
\hline L.M. & $\mathrm{T}_{11^{+}}, \mathrm{T}^{+}$ & 12 & 110 & 112 & 10 & 72 & 82 \\
\hline $\begin{array}{l}\text { E-rosetting } \\
\text { normal } \\
\text { lymphocytes }\end{array}$ & & $5 \pm 1$ & $8 \pm 3$ & $7 \pm 1$ & $4 \pm 2$ & $6 \pm 1$ & $14 \pm 2$ \\
\hline
\end{tabular}

Values represent the increment in deoxyATP or deoxyGTP pools over those in cells incubated in the presence of $10 \mu \mathrm{M} 2^{\prime}$-deoxycoformycin or $100 \mu \mathrm{M}$ of 8-aminoguanosine respectively. Numbers represent the mean \pm SD of three determinations for cell lines and a single determination for patient cells.

${ }^{*}$ Cells were incubated for $4 \mathrm{~h}$ or $24 \mathrm{~h}$ in the presence of $50 \mu \mathrm{M} \mathrm{AdR}$ and $10 \mu \mathrm{M} \mathrm{dCF}$.

$\dagger$ Cells were incubated for $4 \mathrm{~h}$ or $24 \mathrm{~h}$ in the presence of $50 \mu \mathrm{M} \mathrm{GdR}$ and $100 \mu \mathrm{M} 8$-AGuo.

\section{Purine metabolizing enzyme activities}

In order to determine whether any clear correlation exists between purine metabolizing enzyme activity and the relative lack of ability to accumulate deoxynucleoside triphosphates by either fresh or cultured CTCL cells, levels of cytoplasmic deoxycytidine, AdR, and adenosine phosphorylating activities as well as nucleotidase activity were measured. In addition, levels of ADA, PNP, ecto-5'-nucleotidase, and ecto-ATPase activities were determined (Tables IV and V). As had been reported previously (Blatt et al, 1982; Ma et al, 1983), the CTCL cells have lower levels of ADA and higher levels of PNP activity than do the T lymphoblasts. Of particular interest, however, was the low level of ecto- 5 '-nucleotidase activity on CTCL cell lines, a characteristic not shared by the mature leukaemic $\mathrm{T}$ cells which were isolated directly from peripheral blood. The ability of cytoplasmic extracts to phosphorylate deoxycytidine and AdR tended to be lower in CTCL cell lines and patient cells than in $\mathrm{T}$ lymphoblasts, whereas adenosine kinase, cytoplasmic nucleotidase and ectoATPase activities were similar. 
Table III. Changes in ATP pools in lymphoid cell lines incubated with AdR and deoxycoformycin*

\begin{tabular}{lcc}
\hline & \multicolumn{2}{c}{ Incubation time } \\
\cline { 2 - 3 } \multicolumn{1}{c}{ Cell lines } & $4 \mathrm{~h}$ & $24 \mathrm{~h}$ \\
\hline CTCL & & \\
$\quad$ HUT 78 & $+24 \pm 12$ & $-12 \pm 8$ \\
$\quad$ HUT 102 & $+11 \pm 9$ & $-9 \pm 6$ \\
T lymphoblasts & & \\
$\begin{array}{l}\text { MOLT 4 } \\
\text { RPMI 8402 }\end{array}$ & $+19 \pm 12$ & $+5 \pm 6$ \\
B lymphoblasts & $-16 \pm 11$ & $-50 \pm 22$ \\
MGL 8 & $-36 \pm 14$ & $+13 \pm 7$ \\
GM 558 & $-41 \pm 30$ & $+30 \pm 11$ \\
\hline
\end{tabular}

Changes in ATP pools are calculated as the percentage of those in control cells incubated with $10 \mu \mathrm{M} 2$-deoxycoformycin alone (mean \pm 1 SD of three experiments). Negative values reflect a decline in ATP pools.

* Incubations were performed in the presence of $50 \mu \mathrm{M} \mathrm{AdR}$ and $10 \mu \mathrm{M} 2$ '-deoxycoformycin.

Table IV. A comparison of purine metabolizing enzyme activities in lymphoid cells

\begin{tabular}{|c|c|c|c|c|c|}
\hline & $\begin{array}{l}\text { Deoxycytidine } \\
\text { kinase activity }\end{array}$ & $\begin{array}{l}\text { Deoxyadenosine } \\
\text { kinase activity* }\end{array}$ & $\begin{array}{c}\text { Adenosine } \\
\text { kinase activity* }\end{array}$ & $\begin{array}{l}\text { Adenosine } \\
\text { deaminase } t\end{array}$ & $\begin{array}{c}\text { Purine nucleoside } \\
\text { phosphorylase }\end{array}$ \\
\hline \multicolumn{6}{|l|}{ CTCL } \\
\hline HUT 78 & $3 \cdot 7$ & $43 \cdot 7$ & $283 \cdot 7$ & $125 \cdot 5$ & $199 \cdot 5$ \\
\hline HUT 102 & $3 \cdot 9$ & $37 \cdot 0$ & $202 \cdot 4$ & $130 \cdot 8$ & $109 \cdot 3$ \\
\hline \multicolumn{6}{|l|}{ T lymphoblasts } \\
\hline MOLT 4 & $8 \cdot 6$ & $82 \cdot 2$ & $130 \cdot 2$ & $690 \cdot 0$ & $74 \cdot 4$ \\
\hline RPMI 8402 & $24 \cdot 4$ & $128 \cdot 0$ & $122 \cdot 0$ & $870 \cdot 9$ & $40 \cdot 5$ \\
\hline \multicolumn{6}{|l|}{ B lymphoblasts } \\
\hline MGL 8 & $6 \cdot 0$ & $23 \cdot 3$ & $156 \cdot 0$ & $18 \cdot 0$ & $76 \cdot 1$ \\
\hline GM 558 & $8 \cdot 1$ & $58 \cdot 6$ & $201 \cdot 8$ & $19 \cdot 0$ & $62 \cdot 2$ \\
\hline \multicolumn{6}{|l|}{ CTCI patients } \\
\hline E.M. & $13 \cdot 8$ & $67 \cdot 4$ & $261 \cdot 4$ & $129 \cdot 5$ & 263.9 \\
\hline B.K. & $5 \cdot 7$ & $42 \cdot 1$ & $125 \cdot 1$ & $12 \cdot 9$ & $332 \cdot 6$ \\
\hline L.M. & $7 \cdot 11$ & $46 \cdot 4$ & $61 \cdot 2$ & $56 \cdot 9$ & $297 \cdot 0$ \\
\hline
\end{tabular}

Enzyme activities were determined as outlined in methods and represent the mean of duplicate determinations for the cell lines and a single determination on the patients' cells.

${ }^{*} \mathrm{nmol} / \mathrm{h} / \mathrm{mg}$ protein; $\dagger \mathrm{nmol} / \mathrm{min} / \mathrm{mg}$ protein. 
Table V. A comparison of nucleotidase activities in lymphoid cells

\begin{tabular}{|c|c|c|c|}
\hline & $\begin{array}{c}\text { Ecto } 5^{\prime}- \\
\text { nucleotidase }\end{array}$ & $\begin{array}{c}\text { Cytoplasmic } \\
\text { nucleotidase }\end{array}$ & $\begin{array}{c}\text { Ecto- } \\
\text { ATPase* }\end{array}$ \\
\hline \multicolumn{4}{|l|}{ CTCL lines } \\
\hline HUT 78 & $1 \cdot 9$ & $74 \cdot 4$ & $1 \cdot 7$ \\
\hline HUT 102 & 0.5 & $86 \cdot 7$ & $<1 \cdot 0$ \\
\hline \multicolumn{4}{|l|}{ T lymphoblasts } \\
\hline MOLT 4 & 0.1 & $22 \cdot 7$ & $<1 \cdot 0$ \\
\hline RPMI 8402 & $0 \cdot 1$ & $52 \cdot 3$ & $<1 \cdot 0$ \\
\hline \multicolumn{4}{|l|}{ B lymphoblasts } \\
\hline MGL 8 & $33 \cdot 8$ & $56 \cdot 3$ & 1260 \\
\hline GM 558 & $19 \cdot 7$ & $30 \cdot 1$ & 2136 \\
\hline \multicolumn{4}{|l|}{ CTCL patients } \\
\hline E.M. & $32 \cdot 1$ & N.D. & N.D. \\
\hline B.K. & $17 \cdot 6$ & N.D. & N.D. \\
\hline L.M. & $25 \cdot 6$ & N.D. & N.D. \\
\hline
\end{tabular}

\section{DISCUSSION}

The mechanism of cytotoxicity to T lymphocytes in ADA and PNP deficiency diseases has received considerable attention because of the potential for selective pharmacologic manipulation of the immune system. It has become clear from the work of several groups that deoxynucleoside triphosphate accumulation, which has been proposed to inhibit the enzyme ribonucleotide reductase and deplete the cells of other deoxynucleotides required for DNA synthesis, does not suffice to explain the toxic effects of AdR in particular for mature, non-dividing $\mathrm{T}$ lymphocytes (Kefiord \& Fox, 1982; Carson et al, 1982; Lee et al, 1984). Several alternative hypotheses for the toxicity of AdR, in the presence of an ADA inhibitor, for mature T cells have been offered. ATP depletion, observed to occur in erythrocytes of deoxycoformycin-treated patients (Siaw et al, 1980) and in T lymphoblasts exposed to very high AdR concentrations (Bagnara \& Hershfield, 1982), has also been shown to occur in peripheral blood lymphocytes which accumulate dATP in vitro (Carson et al, 1982). There is also some evidence that the polyadenylation of mRNA is altered in the presence of dATP accumulation (Kefford et al, 1983), and that the overall rate of RNA synthesis in resting lymphocytes is decreased (Matsumoto et al, 1983). A third hypothesis to explain lymphocyte depletion involves the inhibition of S-adenosylhomocysteine hydrolase activity by AdR (Hershfield, 1979), leading to the accumulation of S-adenosylhomocysteine and subsequent alterations in S-adenosylmethionine-mediated methylation reactions.

Our study was designed to examine the metabolism of deoxynucleosides by lymphoid cells of mature phenotype. The use of lines obtained from patients with cutaneous $\mathrm{T}$ cell 
leukaemias enabled us directly to compare the cytotoxic potential of AdR, GdR and TdR for these actively growing cells with that for immature $\mathrm{T}$ lymphoblasts. It is clear from these data that the preferential cytotoxicity of these deoxynucleosides for $\mathrm{T}$, as compared to $\mathrm{B}$, lymphoblasts does not extend to the mature $\mathrm{T}$ cell lines. In addition, the capability of these cells to accumulate dATP or dGTP from AdR or GdR, respectively, remains far less than that of the $\mathrm{T}$ lymphoblasts, suggesting that marked differences in purine metabolizing enzyme activities may occur during $\mathrm{T}$ cell maturation.

Despite this supposition, measurements of cytoplasmic enzyme activities revealed only a slight reduction in deoxynucleoside phosphorylating activity in CTCL lines, using both AdR and deoxycytidine as substrates. The true significance of this observation is difficult to determine, given the limited number of cell lines of each type examined and the inability to clearly distinguish differences between $\mathrm{T}$ and $\mathrm{B}$ lymphoblasts on the basis of cytoplasmic kinase activities (Hershfield et al, 1982). In addition, cytoplasmic nucleotidase and ecto-ATPase activities were of little discriminating value. Thus, we cannot determine whether decreases in deoxynucleoside phosphorylating activity and/or increases in nucleotidase activity are responsible for the lesser ability of the mature $\mathrm{T}$ cells to accumulate deoxynucleotides. What has become clear, however, as that low ecto-5'-nucleotidase or ecto-ATPase activity does not directly correlate with the ability of cells to accumulate deoxynucleotides (Fox et al, 1981b; Carson et al, 1981; Mitchell \& Edwards, 1984), a fact which is now further substantiated by the low activity of both enzymes in the CTCL lines we examined.

Data on the clinical responsiveness of patients with mature $\mathrm{T}$ cell neoplasms to $2^{\prime}$-deoxycoformycin therapy are presently quite limited. However, since leukaemic cells of mature T cell phenotype are far more resistant to incubations with $\mathrm{AdR}$ and 2'-deoxycoformycin than are immature $\mathrm{T}$ lymphoblasts, one would have to postulate mechanisms of lymphocytotoxicity in these disorders which differ from those in T-cell acute lymphoblastic leukaemia. Since both the ATP depeletion theory and the abnormal polyadenylation theory depend on the accumulation of AATP, it is unlikely that either plays a leading role in killing mature T cells. Indeed, examination of the ATP pools in the incubated CICL cells did not reveal a major degree of ATP depletion after $24 \mathrm{~h}$, although the levels consistently dropped somewhat below baseline levels. Similarly, simple inhibition of S-adenosylhomocysteine hydrolase by AdR would also be expected to occur in the in vitro setting and hence would not explain the lack of susceptibility of CTCL cells to AdR toxicity. It is certainly possible that inhibition of ADA activity in vivo leads to metabolic consequences which cannot be predicted by simple in vitro incubation systems. Alternately, more extensive clinical data may not support a truly selective toxicity of adenosine deaminase inhibition for mature, malignant $\mathbf{T}$ cells.

\section{ACKNOWLEDGMENTS}

'This work was supported by Grant CA-34085 from the National Cancer Institute. B.S.M. is the recipient of a Scholar Award from the Leukemia Society of America. Y.S. is the recipient of an Elsa Pardee fellowship from the University of Michigan. We appreciate the excellent technical assistance of Elizabeth Ashcraft. 


\section{REFERENCES}

Bagnara, A.S. \& Hershfield, M.S. (1982) Mechanism of deoxyadenosine-induced catabolism of adenine ribonucleotides in adenosine deaminase-inhibited human $\mathrm{T}$ lymphoblastoid cells. Proceedings of the National Academy of Sciences of the United States of America. 79. 2673-2677.

Blatt, J., Bunn, P.A., Carney, D.D., Reaman, G., Sorrey, P. \& Poplack, D.G. (1982) Purine pathway enzymes in the circulating malignant cells of patients with cutaneous T-cell lymphoma. British Journal of Haematology, $\mathbf{5 2}$, 97-104.

Bunn, P.S., Schechter, G.P., Jaffe, E., Bl.ayney, D., Young, R.C., Matthews, M.J., BLattnek, W., Broder, S., Robert-Guroff, M. \& Gallo, R.C. (1983) Clinical course of retrovirus-associated adult T-cell lymphoma in the United States. New England Journal of Medicine, 309, 257-264.

Carson, D.A., Kaye, J. \& Stegmiller, J.E. (1978) Differential sensitivity of human leukemic T-cell lines and B-cell lines to growth inhibition by deoxyadenosine. Journal of Immunology. $121,1726-1731$.

Carson, D.A., Kaye, J. \& Wasson, D.B. (1981) The potential importance of soluble deoxynucleotidase activity in mediating deoxyadenosine toxicity in human lymphoblasts. Journal of Immunology, 126, 348-352.

Carson, D.A., Wasson, D.B., Lakow, E. \& KamaTANI, N. (1982) Possible metabolic basis for the different immunodeficient states associated with genetic deficiencies of adenosine deaminase and purine nucleoside phosphorylase. Proceedings of the National Academy of Sciences of the United States of America, 79, 3848-3852.

Coleman, M.S., Donofrio, J., Hutton, J., Hank, L., Daoud, A., LAmpKin, B. \& Dyminski. J. (1978) Identification and quantitation of adenosine deoxynucleotides in erythrocytes of a patient with adenosine deaminase deficiency and severe combined immunodeficiency. Journal of Biological Chemistry. 253, 1619-1626.

Fox, R.M., KefFord, R.F., TripP, E.H. \& TAYLOR, I.W. (1981a) GI-phase arrest of cultured human leukemic T-cells induced by deoxyadenosine. Cancer Research, 41, 5144-5150.

Fox. R.M., Pidnington. S.K.. TRIPP, E.H. \& TatTER-
SAL, M.H.N. (1981b) Ecto-adenosine triphosphatase deficiency in cultured human $\mathrm{T}$ and null leukemic lymphocytes. A biochemical basis for thymidine sensitivity. Journal of Clinical Investigation, 68, 544-552.

Gazdar, A.F., Carney, D.N., Bunn, P.A., Russell, E.K., JAFFe, E.S., SCHLECHTER, G.P. \& Guccion, L.G. (1980) Mitogen requirements for the in vitro propagation of cutaneous T-cell lymphomas. Blood, 55, 409-417.

Giblett, E.R., Ammann, A.J., Sandman, R.S., WARA, D.W. \& Diamond, L.K. (1975) Nucleoside phosphorylase deficiency in a child with severely defective T-cell immunity and normal B-cell immunity. Lancet, i, 1010-1013.

Giblett, E.R., Anderson, J., Cohen, F.. Pollaka, B. \& MeuWissen, H.I. (1972) Adenosine deaminase deficiency in two patients with severely impaired cellular immunity. Lancet, ii, 1067-1069.

Grever, M.R., Bisaccia, E., Scarborough, D.A., MetZ, E.N. \& NeidharT, J.A. (1983) An investigation of 2-deoxycoformycin in the treatment of cutaneous T-cell lymphoma. Blood, 61, 279-282.

Grever, M.R., Siaw, M.F.E., Jacob, W.F., Neidhar'T, J.A., Miser, J.S., COLEMAN, M.S., HutTon, J.]. \& BALCERZAK, S.P. (1981) The biochemical and clinical conseguences of $2^{\prime}$-deoxycoformycin in refractory lymphoproliferative malignancy. Blood, 57, 406-417.

Hallam, L.J., VanDerWeyden, M.B., Askland, S.P., BAgnaRA, A.S. \& Whiteside, M.G. (1984) The biochemical and clinical consequences of 2 '-deoxycoformycin in T-cell chronic lymphocytic leukaemia. Scandinavian Journal of Haematology, 32, 55-64.

HerShFIELD, M.S. (1979) Apparent suicide inactivation of lymphoblast S-adenosylhomocysteine hydrolase by 2 -deoxyadenosine and adenine arabinoside. Journal of Biological Chemistry, 254, 22-25.

Hershfield, M.S., Fetter, J.E., Small, W.C., BaGNARA, A.S., Will.tiams, S.R., Ulllman, B., MarTIN, D.W., JR, Wasson, D.B. \& CARson, D.A. (1982) Effect of mutational loss of adenosine kinase and deoxycytidine kinase on deoxy ATP accumulation and deoxyadenosine toxicity in cultured CEM human T-lymphoblastoid cells. 
Journal of Biological Chemistry, 257 , 6380-6386.

HuRLEY, M.C. \& Fox, I.H. (1983) Measurement of nucleoside kinases in crude tissue extracts. Biochemical Medicine, 30, 89-100.

Kazmers, I.S., Mitchell, B.S., Daimiona, P.E., WotRing, L.L., TOWNSEND, L.B. \& KeLLEY, W.N. (1981) Inhibition of purine nucleoside phosphorylase by 8-aminoguanosine: selective toxicity for T-lymphoblasts. Science, 214 , $1137-1139$.

KEFFORD. R.F. \& Fox, R.M. (1982) Deoxycoformycin-induced response in chronic lymphocytic leukaemia: deoxyadenosine toxicity in nonreplicating lymphocytes. British Journal of Haematology, 50, 627-636.

Kefford, R.F., Fox, R.M., McCairns, F., Fahey, O., Muscat, G.E.O. \& Rowe, P.B. (1983) Terminal incorporation of 2 '-deoxyadenosine into polyadenylate segments of polyadenylated RNA in $\mathrm{G}_{1}$-phase arrested human T-lymphoblasts. Cancer Research, 43, 2252-2257.

I.e., N., Russell, N., Gareshaguru, K., Jackson, B.F.A., Piga, A., Prentice, H.G., FoA, R. \& HofFbrand, A.V. (1984) Mechanisms of deoxyadenosine toxicity in human lymphoid cells in vitro: relevance to the therapeutic use of inhibitors of adenosine deaminase. British Journal of Haematology, 56, 107-119.

LeONARD, W.J., DEPPER, J.M., RoBb, R.J., WALDMANN, T.A. \& GREENE, W.C. (1983) Characterization of the human receptor for T-cell growth factor. Proceedings of the National Academy of Sciences of the United States of America, 80, 6957-6961.

Ma, D.D.F., Massaia, M., Sylwestrowicz, T.A., Price, G. \& Hofrbrand, A.V. (1983) Comparison of purine degradative enzymes and terminal deoxynucleotidyl transferase in $\mathrm{T}$ cell leukaemias and in normal thymic and post-thymic T cells. British Journal of Haematology, 54, $451-457$.

Matsumoto, S.S., YU, J. \& Yu, A.L. (1983) Inhibition of RNA synthesis by deoxyadenosine plus deoxycoformycin in resting lymphocytes. Journal of Immunology, 131, 2762-2766.

Mitchell, B.S. \& EDWARd, N.I. (1984) Purine metabolizing enzymes as predictors of lymphoblast sensitivity to deoxyadenosine. Journal of Laboratory and Clinical Medicine, 104, 414-424.
Mi'TChell, B.S., Koller, C.A. \& Heyn, R. (1980) Inhibition of adenosine deaminase activity results in cytotoxicity to T-lymphoblasts in vivo. Blood, 56, 556-559.

Mitchell, B.S., Mejias, E., DaddonA, P.E. \& Kelley, W.N. (1978) Purinogenic immunodeficiency diseases: selective toxicity of deoxyribonucleosides for T-cells. Proceedings of the National Academy of Sciences of the United States of America. 75, 5011-5014.

Poiesz, B.J., Ruscetti, F.W., Gazdar, A.F., Bunn, P.A., Minna, J.D. \& Gallo, R.C. (1980) Detection and isolation of type $C$ retrovirus particles from fresh and cultured lymphocytes of a patient with cutaneous T-cell lymphoma. Proceedings of the National Academy of Sciences of the United States of America, 77, 7415-7419.

Prentice, H.G., I.eE, N., Blacklock, H., Smyth, J.F., Russel, N.H., Ganeshaguru, K., Piga, A. \& HoffBrand, A.V. (1981) Therapeutic selectivity of and prediction of response to 2'-deoxycoformycin in acute leukaemia. Lancet, ii, 1250-1254.

Schnitzer, B., LovetT, E., Hudson, J., McCatchey, K., Keren, D., DABICh, L. \& MitchelL, B. (1982) Adult T-cell leukaemia-lymphoma with unusual phenotype. Lancet, ii, 1273-1274.

SiaW, M.F.E., Mitchell, B.S., Koller, C.A., ColEMAN, M.S. \& HutTon, J.J. (1980) ATP depletion as a consequence of adenosine deaminase inhibition in man. Proceedings of the National Academy of Sciences of the United States of America, 77, 6157-6161.

SMYTH, J. (1979) Selective treatment of lymphoid malignancy with adenosine deaminase inhibitors in enzyme defects and immune dysfunction. Ciba Foundation Symposium Amsterdam: Excerpta Medica, 68, 263-272.

Sylwestzowicz, T., Piga, A., Murphy, P., Ganfeshaguru, K., Russell, N.H., Prentice, H.G. \& HoffBrand, A.V. (1982) The effects of deoxycoformycin and deoxyadenosine on deoxyribonucleotide concentrations in leukaemic cells. British Journal of Haematology, 51, 623-630.

WortmanN, R., Mitchell, B.S., EdWARDS, N.L. \& Fox, I.H. (1979) Biochemical basis for differential deoxyadenosine toxicity to $\mathrm{T}$ and $\mathrm{B}$ lymphoblasts: role for 5 'nucleotidase. Proceedings of the National Academy of Sciences of the United States of America, 76, 2434-2437. 